Section Editor

Mitchell S.V. Elkind, MD, MS

Akira Ogose, MD

Tetsuo Hotta, MD

Hiroyuki Kawashima, MD

Hiroshi Yamagiwa, MD

Naoto Endo, MD

Hajime Umezu, MD

Correspondence to

Dr. Ogose:

aogose@med.niigata-u.ac.jp

\section{Teaching NeuroImages: \\ Recurrence of a sural intraneural ganglion cyst after sural nerve resection}

Figure 1 Photograph of the multinodular mass, leg MRI, excised sural nerve, and histologic specimen

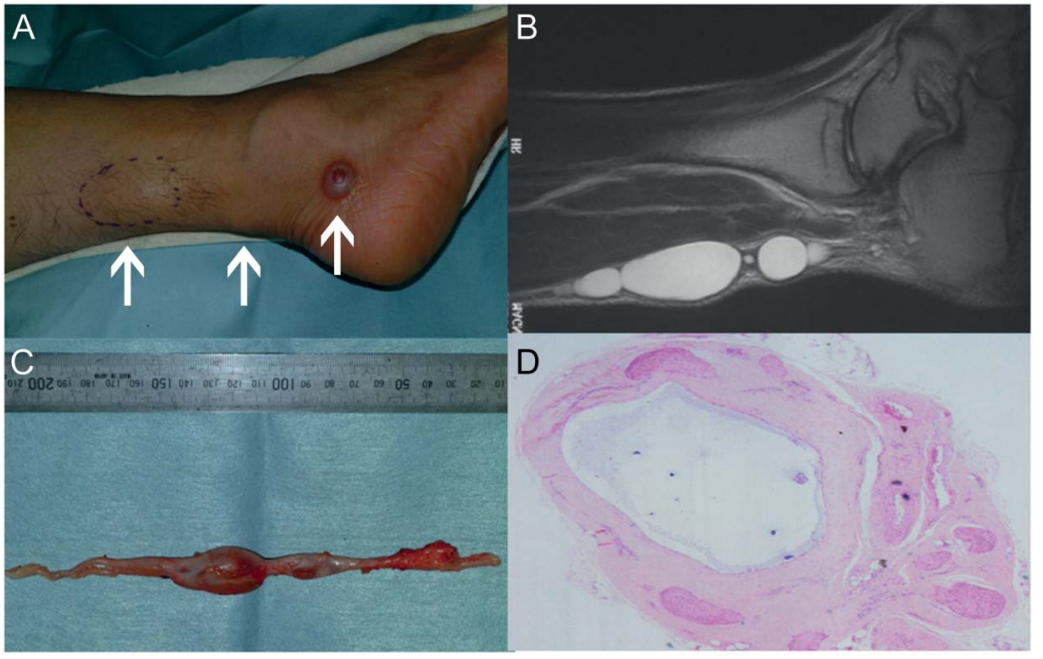

(A) Photograph shows the multinodular tumoral mass (arrows). (B) MRI shows intraneural multiple cysts in the nerve with very high intensity in T2-weighted image. (C) Excised sural nerve and (D) histologic specimen show a large cystic space in the nerve.

Figure 2 Photograph of the recurrent mass and ankle MRI

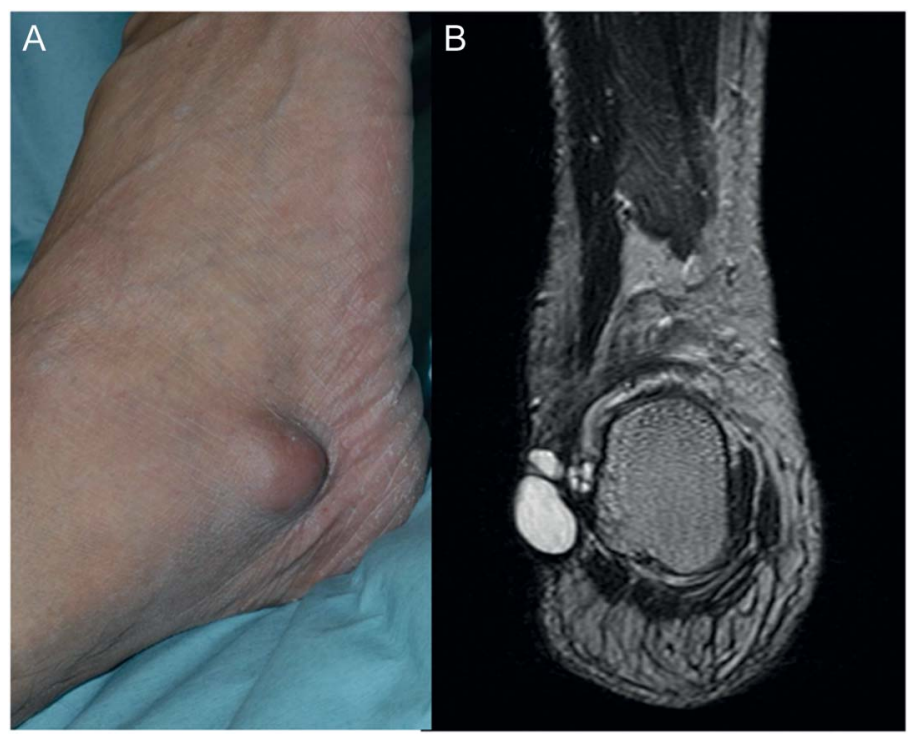

(A) Photograph and (B) MRI show the recurrent cyst originating from the subtalar joint. Arrows show connection of the cyst and the joint.
Download teaching slides: Neurology.org
From the Division of Orthopedic Surgery (A.O., T.H., H.K., H.Y., N.E.), Graduated School of Medical and Dental Sciences, Niigata University; and the Division of Pathology (H.U.), Niigata University Hospital, Japan.

Go to Neurology.org for full disclosures. Funding information and disclosures deemed relevant by the authors, if any, are provided at the end of the article. 
A 57-year-old man presented with a painful multinodular tumoral mass developing, over 7 months, in the lateral part of his right leg. MRI demonstrated a multinodular sural intraneural ganglion cyst. The swollen sural nerve was surgically removed, and the tumor adhered to the subtalar joint. The surgical specimen revealed an intraneural ganglion cyst (figure 1). Sixteen months after the surgery, the tumor recurred and was excised with the adhered subtalar joint capsule (figure 2). The recurring cyst was not connected to the peripheral nerve. This case highlights the synovial (articular) origin of intraneural ganglion cysts. ${ }^{1}$

\section{AUTHOR CONTRIBUTIONS}

A.O.: study concept and design, acquisition and interpretation of data, writing of draft manuscript. T. Hotta, H. Kawashima, H. Yamagiwa, N. Endo, H. Umezu: discussion of case and revision of manuscript.

\section{STUDY FUNDING}

No targeted funding reported.

\section{DISCLOSURE}

The authors report no disclosures relevant to the manuscript. Go to Neurology.org for full disclosures.

\section{REFERENCE}

1. Spinner RJ, Amrami KK, Elshekh MAH, et al. Sural intraneural ganglion cysts are joint-related. Arch Plast Surg 2012;39:77-79. 


\section{Neurology}

\section{Teaching NeuroImages: Recurrence of a sural intraneural ganglion cyst after sural nerve resection}

Akira Ogose, Tetsuo Hotta, Hiroyuki Kawashima, et al. Neurology 2014;83;e95-e96

DOI 10.1212/WNL.0000000000000714

\section{This information is current as of August 18, 2014}

\section{Updated Information \& Services}

Supplementary Material

\section{References}

Subspecialty Collections

Permissions \& Licensing

Reprints including high resolution figures, can be found at: http://n.neurology.org/content/83/8/e95.full

Supplementary material can be found at: http://n.neurology.org/content/suppl/2014/08/15/WNL.0000000000000 714.DC1

This article cites 1 articles, 0 of which you can access for free at: http://n.neurology.org/content/83/8/e95.full\#ref-list-1

This article, along with others on similar topics, appears in the following collection(s):

Nerve tumor

http://n.neurology.org/cgi/collection/nerve_tumor

Neuropathic pain

http://n.neurology.org/cgi/collection/neuropathic_pain

Peripheral neuropathy

http://n.neurology.org/cgi/collection/peripheral_neuropathy

Information about reproducing this article in parts (figures,tables) or in its entirety can be found online at:

http://www.neurology.org/about/about_the_journal\#permissions

Information about ordering reprints can be found online:

http://n.neurology.org/subscribers/advertise

Neurology ${ }^{\circledR}$ is the official journal of the American Academy of Neurology. Published continuously since 1951, it is now a weekly with 48 issues per year. Copyright @ 2014 American Academy of Neurology. All rights reserved. Print ISSN: 0028-3878. Online ISSN: 1526-632X.

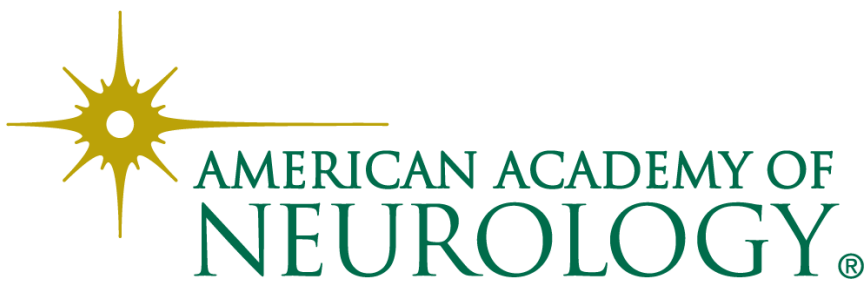

